\title{
Relationship between Selected Leadership Style and Employee Stress Level at Workplace
}

\author{
Choi Mui Fong ${ }^{1}$ \\ Florianna Lendai ak Michael Mulok ${ }^{2 *}$ \\ Helmi Sumilan ${ }^{3}$

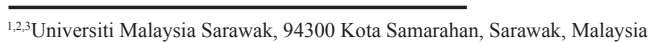

\begin{abstract}
There has been only limited research focused on the assumption of leader stress and affective well-being. Hence, this study aims to determine the relationship between leadership style and employee stress level at workplace. This study primarily took a quantitative approach for data collection and analysis. Questionnaires were distributed at three branches of banks located in Kuching, Sarawak and to their employees. The findings show that there is a relationship between autocratic leadership style and employee stress level at workplace. The strength of the relationship is weak due to $r=$ $.461, p=.002$. The findings also show that democratic leadership and transformational leadership have no relationship with the employee stress level at workplace.
\end{abstract}

Keywords: leadership style; employee stress

\section{INTRODUCTION}

Previously, researchers primarily focused on the effects of stress on employees' performance, whereas the employee stress level and leadership style was often ignored. Choi (2007) highlighted that from earliest to current history, leadership has important role in developing groups, ethnicity, and countries; and Maqsood (2013) stated that leadership style is one of the factors that contributes to achieving organizational

\section{ARTICLE INFO}

E-mail address:

mmflendai@unimas.my (Florianna Lendai ak Michael

Mulok)

*Corresponding author

ISSN: 2462-1153

(C) Faculty of Cognitive Sciences and Human Development, Universiti Malaysia Sarawak (UNIMAS) goals. Romanowska, Larsson, and Theorell (2013) have shown that leadership has an important role in the organization because it is carried with a duty to assume responsibility, while bad leadership may bring distress for every member who is affected by it. In order to ensure the organization runs smoothly and successfully, it requires the right leader and the right leadership style to face the unique challenges which lead to the organization success (Rao, 2013). Gurt, Schwennen, and Elke (2011) found that the 
impact of employee health is dependent on a mixture of leadership behaviours and style. Skakon, Nielsen, Borg, and Guzman (2010) stated that there has been only limited research focused on the assumption of leader stress and affective well-being. At the workplace, stress is an unpleasant state that can lead to a long-term influence, whereby it can produce a negative impact on health, performances and productivity. Chen and Silverthorne (2005) have found that the leadership style, on-the-job performance, satisfaction, stress, and turnover intention are related. Therefore, this research looked into the three most common leadership styles, namely, autocratic, democratic and transformational that affect the employee stress level at workplace.

\section{OBJECTIVES AND HYPOTHESES}

The objectives of the study are as follows:

i. To identify the relationship between autocratic leadership and the employee stress level at workplace.

ii. To identify the relationship between democratic leadership and the employee stress level at workplace.

iii. To identify the relationship between transformational leadership and the employee stress level at workplace.

The research hypotheses are as follows:

$\mathbf{H}_{\mathbf{0}} \mathbf{1}$ There is no relationship between autocratic leadership and the employee stress level at workplace.

$\mathbf{H}_{\mathbf{0}} \mathbf{2}$ There is no relationship between democratic leadership and the employee stress level at workplace.

$\mathbf{H}_{\mathbf{0}} 3$ There is no relationship between transformational leadership and the employee stress level at workplace.

\section{LITERATURE REVIEW}

Any leader needs to be aware that there are many ways to lead people, so they must adapt their leadership style to the current situation they are facing (Casse \& Claudel, 2011). A good and successful leader does not have to be intelligent and well-educated, as long as they need to understand people on how they feel, their thought and their concerns (Darling \& Heller, 2011). Naile and Selesho (2014) stated that a leader has the power to affect others and would not essentially be a manager; it can be another person who can have leadership ability and also can be a manager. Leadership may be viewed as a key resource for building and maintaining teams of employees in the organization through developing employee skills (Johansson, 2004). Moreover, according to Mendez, Munoz, and Munoz (2013), a leader can be determined by a person who has a group of people and those people on whom he or she applies his or her power are identified as subordinate in order to achieve the desired objectives. Bhatti, Maitlo, Shaikh, Hashmi, and Shaikh (2012) stated that a leader is a mentor, coach, communicator, co-ordinator, and listener. The leader's behaviour and personality have a significant effect on the way they think, feel and respond to people in their surroundings (Alkahtani, Abu-Jarad, Sulaiman, \& Nikbin, 2011). When the leader consults with the employee and considers their opinions before making decisions, it can enhance the employees' ability to deal with emotional exhaustion (Mulki, Jaramillo, \& Locander, 2006). Leadership can be representing as a person that influences employees and enhances employee performance (Che Ngah, Fazli Musa, Noreen Rosli, Norisaifulruddin, Mohd, Ariffin, \& Krishnan, 2013). Leadership style can essentially be either stressful or positive for employees, and as 
a result it affects their levels of stress and influence employees' well-being (Skakon et al., 2010).

\section{Autocratic Leadership}

Autocratic leadership has high level of control by the leaders and less participation of employees in group decisions (Choi, 2007). Leader usually uses his/ her individual power and authority to influence employees and is strict as well as prefers to keep close supervision. Moreover, leaders like to take control over the decisions in order for anything to be done. Autocratic leader is in charge and in control of his or her followers to lead to the success of the organization and these followers are compliant employees (Jayasingam \& Cheng, 2009). This type of leader informs his or her employees what and how they should do to complete the task given (Alkahtani et al., 2011). Mendez et al. (2013) state that autocratic leader is likely to focus on the authority by making unilateral choice and limits the participation of employees. Autocratic leader is characterized by making all the decision without considering employees opinion and using top-down communication (Gonos \& Gallo, 2013). Ojokuku, Odetayo, and Sajuyigbe (2012) emphasize that autocratic leadership does not implement shared vision, commitment, and innovation with its followers.

\section{Democratic Leadership}

Democratic leadership enhances discussion and knowledge sharing and encourages employees to feel exceptional about their participation in decision process (Malos, 2012). Meanwhile, Bhatti et al. (2012) stated that democratic leader encourages each of the team members to generate and contribute ideas in the decision making process and is the most efficient in terms of maintaining self-confidence at workplace. The democratic leaders use friendly approach to communicate with employees and they are categorized by the two-way communication between the leader and employees and allows the employee to participate in conducting evaluation and analyzing the achieved results together (Gonos \& Gallo, 2013). The main point of the democratic leader is providing information and sharing knowledge towards each of the employee in his or her group (Choi, 2007). Mendez et al. (2013) emphasized that democratic leader corresponds to the person in charge who generally involves employees in the decision-making and considers their needs, through assigning authority. This style of leadership includes the concept that every employee must play a role in the group's decisions making (Malos, 2012). Democratic leaders build up their power effectively and seek to overcome barriers in front of them with the support of their followers (Choi, 2007).

\section{Transformational Leadership}

Transformational leaders use visionary and creative ideas to influence their followers (Munir, Nielsen, \& Carneiro, 2010). In addition, Martinette (2002) shows that transformational leadership provides effective strategies for achieving organization vision. According to Rao (2013), transformational leadership develops values and ethics among the employees and expresses trust in their team members. This leadership style raises the employees in the hierarchy of needs by converting their values through the leader's ability to create a clear organizational vision (Islam, Rehman, \& Ahmed, 2013). Transformational leader generates an understanding of the importance of attaining valued result by defining shared values and thought (Martinette Jr, 2002). Transformational leaders make 
Choi Mui Fong, Floriana Lendai ak Michael Mulok, and Helmi Sumilan

a good relationship with their employees and encourage them to look beyond their own requirements to enhance the performance of employees and also the organizational performance (Alkahtani et al., 2011). Transformational leaders have an individualized view of each employee and they consider their employees' needs and personal development (Rohmann \& Rowold, 2009). Meanwhile, Fitzgerald and Schutte (2010) stated that transformational leadership is a motivational approach which includes a good communication with employees and understanding employees' needs which contributes to the best achievement of goals of an organization.

\section{Leadership Style and Employees Stress Level}

Leadership style can essentially be either stressful or positive for employees, and as a result it affects their levels of stress and influences employees' well-being (Skakon et al., 2010). Employees will enjoy working with good leader where they gain satisfaction and have less stress (Mansor, Kamarudin, \& Zakaria, 2012). This can be proved based on Erkutlu and Chafra (2006), where they found that strong social support from leader helps employee cope positively with stressful as well as contributing to their psychological and physical well-being. Autocratic leadership behaviour could lead to high levels of stress and low well-being among employees (Skakon et al., 2010). This is proven by previous research on Dhamodharan and Arumugasamy (2011) who studied about leadership style and employee stress and found that employee stress has influencing effect on the leadership style. In addition, abusive leader brings harmful effect which makes employees dissatisfied with the job and causes poor mental health (Lin, Wang, \&
Chen, 2013). In another study conducted by Nami, Mansouri, Dehnavi, and Bandali (2013) to investigate the relationship between coaches' leadership styles and athletes' stress, it was found that there is a significant relationship between athletes' stress and coaches' leadership styles of autocratic. Gonos and Gallo (2013) found that a majority of the top management uses punishment to motivate the employees. According to Maqsood (2013), previous studies have stated that the democratic leadership which encourages the employees in decision making process can increase the employee's job satisfaction and reduce employee's stress level. Meanwhile, manager with a transformational leadership style could assist towards defending employees from developing stress (Munir, 2010). Gill, Flaschner, and Shachar (2006) examined the influences of transformational leadership on job stress and the results show that the more a manager's leadership is perceived as transformational, the less the job stress on his or her employees. Voon, Lo, Ngui, \& Ayob (2011) discovered that transformational leadership is believed to be suitable for managing the organizations. Besides, researchers also found that each dimension of employee stress is influenced by at least one type of social support such as management, leadership style and coworkers (Lundqvist, Eriksson, \& Ekberg, 2012).

\section{METHODOLOGY}

This study used quantitative research method in collecting the data through statistical procedures. According to Zehir, Sehitoglu, and Erdogan (2012), a field survey using questionnaires is needed to determine the relationship between independent variable and dependent variable. In this research, cross-sectional design is used to verify the dissimilarity and similarity of a differ- 
ent group of people in a certain time. According to Rusli Ahmad and Hasbee Usop (2014), cross-sectional study is to identify the pattern of relationship between two variables whether it is a direct causal relationship or indirect causal relationship. Pearson correlation is used in this study to determine the relationship between the independent and dependent variable. The dependent variable is level of stress among the employee who worked in banking sector and the independent variables are types of leadership (autocratic, democratic, and transformational leadership). This research was conducted at three branches of a bank which is located in Kuching, Sarawak. Information obtained and collected for the study is from the population consisting of managers and employees. The total population was 56 employees and the sample size was derived from Krejcie and Morgan (1970) formula which is 48. A simple random sampling was used to obtain a sample in this study. One advantage of a simple random sampling is that every member of the population has an equal opportunity to be included in the sample (Chua, 2012). The sampling frame is generated based on the list of registered employees in the banks. Another advantage of a simple random sampling is that it makes data collection easier and can be obtained from the respondents easily without wasting time. This method also can avoid personal bias in selecting a sample.

\section{Research Instruments}

All the information and data were collected through close-ended questionnaires that are divided into three sections. The questionnaires were designed based on the past research and modified based on results from the pilot study which was conducted. The research questionnaires were written in both English and Bahasa Malaysia to enhance the understanding of the respondents in completing the questionnaires. The questionnaire is divided into three sections which included in Section A (respondent demographic which records the personal profile), Section B (Autocratic leadership style items from 1-6, democratic leadership style question from 7-12, transformational leadership style items from 13-18) and Section $\mathrm{C}$ which consists of 12 items to determine the employees' stress level. The constructs in this study were developed by using measurement scales taken from previous studies and it is measured by using four-point Likert scale. From (1) "Strongly Disagree" to (4) "Strongly Agree". Pilot test was then conducted to verify the content and format of survey questionnaire. Close-ended questionnaire was prepared and given to the supervisor to review. Cronbach Alpha Coefficient test in Statistical Package of Social Sciences (SPSS) version 20 was used to analyze the collected data. All the variables have Alpha Coefficient values exceeding 0.70 which showed that research instruments in each variable have exceeded the minimum standard of reliability.

\section{DATA COLLECTION AND ANALYSIS}

Formal letters of survey approval application were sent to the branch manager. After the application was approved, 56 sets of the questionnaires were distributed to the bank employees. The survey questionnaires were filled by bank employees based on a voluntary basis. Respondents were given three weeks to fill up the questionnaire to ensure that the respondent had enough time to understand the questions. When the questionnaires were returned, data were entered into an electronic database setup to store the confidential data. A total of 41 sets $(73.2 \%)$ of the questionnaire forms were collected back. Means, descriptive analysis, and correlation analy- 
sis were performed on the data and data were analysed by using the Statistical Package for the Social Sciences (SPSS) computer program version 20.

\section{FINDINGS AND DISCUSSION}

Relationship between autocratic leadership and the employee stress level

The first hypothesis stated that there is no relationship between autocratic leadership and the employee stress level. Table 1 shows that the mean of autocratic leadership is 2.69 and the standard deviation is .42 and the mean of employee stress level is 2.11 and the standard deviation is .44. Table 1 also shows that the strength of the relationship is low as $r$ value falls in the category of low positive correlation $(r=+0.30$ to +0.59$)$. The results indicated that there is a significant and low positive relationship exists $(r=.46, p=.002$ at $p$ $<0.05$ ) between autocratic leadership and employee stress level. Therefore, the hypothesis $\left(\mathrm{H}_{0} 1\right)$ was rejected.

This result indicates that when the leader is using autocratic leadership style in the workplace, the employee becomes stressful and this proved that autocratic leadership has an influence on the employee stress level. This finding was supported by Dhamodharan and Arumugasamy (2011) who conducted a research on executives working in public sector in Tamil Nadu and found that majority of executive employees follow autocratic style of leadership and 81 executives have moderate stress and 73 have high stress level. Based on previous research, autocratic leader- ship behaviour could lead to high levels of stress and low well-being among employees (Skakon et al., 2010). Nami et al. (2013) also found that there is a significant relationship between leadership styles and stress in team sports from the University of Tehran. Moreover, Erkutlu and Chafra (2006) conducted a study to determine the influence of leadership power based on subordinates' job stress at boutique hotels and found that there are significant relations between leader power bases and subordinates' job stress. It was found that job stress was affected by leadership powers. This result also supported the findings of Nyberg, Holmberg, Bernin, Alderling, Akerblom, Widerszal-Bazyl, Magrin, Hasselhorn, Milczarek, D'Angelo, Denk, Westerlund, and Theorell (2011) who found out autocratic leadership was significantly associated with poor mental health and high behavioural stress. Based on the previous study, we can conclude that autocratic leadership had influence on the employee stress level at workplace.

\section{Relationship between democratic lead- ership and the employee stress level}

The second hypothesis stated that there is no relationship between democratic leadership and the employee stress level. From Table 2, it shows that the mean of democratic leadership is 1.81 and standard deviation is .33 , and the mean of employee stress level is 2.11 and the standard deviation is .44 . Results revealed there is no significant and no correlation exists $(r=.04$, $p=.81$ at $p>.05$ ) between democratic leadership and employee stress level. There-

Table 1: Correlation between autocratic leadership and employee stress level

\begin{tabular}{lcccc}
\hline \hline Variables & $M$ & $S D$ & $\begin{array}{c}\text { Pearson correlation } \\
(r)\end{array}$ & $\begin{array}{c}\text { Significance } \\
(p)\end{array}$ \\
\hline Autoc ratic Leadership & 2.69 & .42 & .46 & .002 \\
Employee Stress Level & 2.11 & .44 & - & - \\
\hline \hline
\end{tabular}


Choi Mui Fong, Floriana Lendai ak Michael Mulok, and Helmi Sumilan

fore, the hypothesis $\left(\mathrm{H}_{\mathrm{o}} 2\right)$ was accepted.

This result explained that leader using democratic leadership style in the workplace does not influence the employee stress level. According to Maqsood (2013), previous studies have stated that the democratic leadership which encourages the employees in decision making process can increase the employee's job satisfaction and reduce employee's stress level. Bhatti et al. (2012) had conducted a research on the impact of democratic leadership style on job satisfaction in public and private schools that shows that the employees are more satisfied when the leader implements democratic leadership style. Colligan and Higgins (2005) found that the employees' stress does have a direct relationship to the characteristics of the stressor and employee's personal characteristics. However, it does not have any relationship towards leadership style.

Relationship between transformational leadership and the employee stress level

The third hypothesis stated that there is no relationship between transformational leadership and the employee stress level. Table 3 shows that the mean transformational leadership is 3.07 and standard deviation is .48 , and the mean of employee stress level is 2.12 and the standard deviation is .44 . The results indicate that there is no significance $(r=-.08, p=.63$ at $p>.05)$ between transformational leadership and employee stress level. Therefore, the hypothesis $\left(\mathrm{H}_{0} 3\right)$ was accepted.

This result indicates that leader using transformational leadership style in the workplace did not has an influence on the employee stress level. Yao et al. (2014) explore the influences of transformational leadership and work stress on employee. According to the data analysis, the results show that transformational leadership negatively influences the work stress on employee. Gill, Flaschner, and Shachar (2006) conducted a study to determine the impact of transformational leadership on work stress and found that transformational leadership is not related to work stress. Shafie, Baghersalimi, and Barghi (2013) determined the relationship between leadership style and employees' performance in Tehran. The results showed that there is a significant relationship between transformational leadership and employee performance. Besides, there is a study which investigated the relationship between employee stress and performance and this study proved that when employee suffer from stress, it result in low job satisfaction and poor performance (Leung, Chan, \& Dongyu, 2011). Therefore, these findings were supported by previous literature and they strengthened the previous research.

\section{IMPLICATIONS OF DIFFERENT LEADERSHIP STYLES FOR EM- PLOYEES' STRESS}

The way a leader makes decisions, delegates responsibility and interacts with employees can affect the entire organization. A leader with democratic leadership is always most favourable as this type of leader usually is able to accept inputs from employees and utilize pertinent informa-

Table 2: Correlation between democratic leadership and employee stress level

\begin{tabular}{lcccc}
\hline \hline Variables & $M$ & $S D$ & $\begin{array}{c}\text { Pearson correlation } \\
(r)\end{array}$ & $\begin{array}{c}\text { Significance } \\
(p)\end{array}$ \\
\hline Democratic Leadership & 1.81 & .33 & .04 & .81 \\
Employee Stress Level & 2.11 & .44 & - & - \\
\hline
\end{tabular}


tion to ensure that the task is complemented in a more efficient manner. Autocratic leader tends to alienate the employees and this might diminish the employee of sense of belongingness to an organization and lead to low productivity. However, the democratic leaders are usually more open to employees' involvement and they allow employees to feel part of the company's success. This study proves that leadership styles do indeed have influence on the stress level of the employees and this in turn would somehow lead to the productivity of the staff and to the productivity of the organization.

\section{RECOMMENDATIONS FOR FU- TURE STUDY}

This study can be used as guidelines by management to improve the leadership styles at the workplace. The ability of leaders to choose the appropriate leadership style that meets the current organization changes could help the leader becomes a successful leader. This research banks may produce different findings as they may be influenced by other factors. Future research can study on other private sector and government sector to identify the relationship between leadership style and employee stress level in different organizations. The findings could be different and can get more accurate results based on large population and sample size. In addition, using multiple ways such as interviews may help the researcher collect and obtain more valid data.

\section{CONCLUSION}

This study provides a better understanding of leadership style and employee stress level at workplace based on leadership theories. Based on this study, human resource practitioners can have better understanding of the factors that influence employee stress level at workplace. According to the findings, democratic leadership style is considered to be more favorable as it shows there is relationship between the style and the employees' stress. Hence, it is

Table 3: Correlation between transformational leadership and employee stress level

\begin{tabular}{lcccc}
\hline \hline Variables & $M$ & $S D$ & $\begin{array}{c}\text { Pearson correlation } \\
(r)\end{array}$ & $\begin{array}{c}\text { Significance } \\
(p)\end{array}$ \\
\hline Transformational Leadership & 3.07 & .48 & -.08 & .63 \\
Employee Stress Level & 2.12 & .44 & - & - \\
\hline
\end{tabular}

focused only on three types of leadership styles, thus future researchers can use other leadership styles such as laissez faire, transactional, participative, consultative and the like to identify the influences on employee stress level. Different types of leadership will generate different types of results which affect the employee stress level at workplace. Besides, this study only focused on employees who work at the bank. Since, the data were collected only from three bank branches, other vital for organization to take into account the type of leadership that would be able to create a more productive environment to the employees for the betterment of the organization.

\section{REFERENCES}

Alkahtani, A. H., Abu-Jarad, I., Sulaiman, M., \& Nikbin, D. (2011). The impact of personality and leadership styles on leading change capability 
Choi Mui Fong, Floriana Lendai ak Michael Mulok, and Helmi Sumilan

of Malaysian managers. Australian Journal of Business and Management Research, 1(2), 70-99.

Bhatti, N., Maitlo, G. M., Shaikh, N., Hashmi, M. A., \& Shaikh, F. M. (2012). The impact of autocratic and democratic leadership style on job satisfaction. International Business Research, 5(2), 192-201.

Casse, P., \& Claudel, P. (2011). Leadership styles : A powerful model. Training Journal, January, 46-51.

Che Ngah, H., Fazli Musa, M., Noreen Rosli, Z., Norisaifulruddin, M. B., M., Mohd, Z. A., Ariffin, A., \& Krishnan, S. N. G. (2013). Leadership styles of general managers and job satisfaction antecedent of middle managers in 5-star hotels in Kuala Lumpur, Malaysia. Asian Social Science, 9(15), 220-226.

Chen, J. C., \& Silverthorne, C. (2005). Leadership effectiveness, leadership style and employee readiness. Leadership \& Organization Development Journal, 26(4), 280-288.

Choi, S. (2007). Democratic leadership : The lessons of exemplary models for democratic governance. International Journal of Leadership Studies, 2, 243-262.

Chua, Y. P. (2012). Mastering research methods. Malaysia: McGraw Hill Education.

Colligan, T.W., \& Higgins, E. M. (2005). Workplace stress: Etiology and consequences. Journal of Workplace Behavioral Health, 21(2), 89-97.

Darling, J. R., \& Heller, V. L. (2011). The key for effective stress management: Importance of responsive leadership in organizational development. Organization Development Journal, 20(1), 9-26.

Dhamodharan, K., \& Arumugasamy, G.
(2011). Effect of occupational stress on executives' leadership styles. Public Policy and Administration Research, 1(4), 1-7.

Erkutlu, H. V., \& Chafra, J. (2006). Relationship between leadership power bases and job stress of subordinates from boutique hotels. Management Research News, 29(5), 285-297.

Fitzgerald, S., \& Schutte, N. S. (2010). Increasing transformational leadership through enhancing selfefficacy. Journal of Management Development, 29(5), 495-505.

Gill, A. S., Flaschner, A. B., \& Shachar, M. (2006). Mitigating stress and burnout by implementing transformational-leadership. International Journal of Contemporary Hospitality Management, 18(6), 469-481.

Gonos, J., \& Gallo, P. (2013). Model for leadrship style evaluation. Management, 18(2), 157-168.

Gurt, J. G., Schwennen, C., \& Elke, G. (2011). Health-specific leadership: Is there an association between leader consideration for the health of employees and their stain and well being?. Work and Stress, 25 (2), 108-127.

Islam, T., Rehman, S. U., \& Ahmed, I. (2013). Investigating themediating role of organizational politics between leadership style and followers'behavioral outcomes. Business Strategy Series, 14(2), 80-96.

Jayasingam, S., \& Cheng, M. Y. (2009). Leadership style and perception of effectiveness: Enlightening Malaysian managers. Asian Social Science, 5(2), 54-65.

Johansson, O. (2004). A democratic, learning and communicative leadership?. Journal of Educational Administration, 42(6), 697-707.

Krejcie, R. V., \& Morgan, D. W. (1970). 
Determining sample size for research activities. Educational \& Psychological Measurement, 30, 607-610.

Leung, M., Chan, Y. S. I., \& Dongyu, C. (2011). Structural linear relationships between job stress, burnout, physiological stress, and performance of construction project managers. Engineering, Construction and Architectural Management, 18(3), 312-328.

Lin, W., Wang, L., \& Chen, S. (2013). Abusive supervision and employee well-being: The moderating effect of power distance orientation. $A p-$ plied Psychology, 62(2), 308-329.

Lundqvist, D., Eriksson, A. F., \& Ekberg, K. (2012). Exploring the relationship between managers' leadership and their health. Work (Reading, Mass.), 42(3), 419-27.

Martinette Jr. C. V. M. (2002). Learning organizations and leadership style. An applied research project submitted to the National Fire Academy, Virginia, (September), 1-58. Malos, R. (n.d). Leadership styles. (Unpublished doctoral dissertation). University of Resita, Romania.

Malos, R. (2012). Leadership styles. Annals of Eftimie Murgu University Resita, Fascicle II, Economic Studies, 421-426.

Maqsood, S. (2013). Manager's leadership styles and employee's job satisfaction. Human and Social Science Research, 1(2), 139-144.

Mendez, R. M., Munoz, J. G. S. V., \& Munoz, M. A. M. V. (2013). Leadership styles and organizational effectiveness in small construction business in Puebla, Mexico. Global Journal of Business Research, 7(5), 47-57.

Mulki, J. P., Jaramillo, F., \& Locander, W.
B. (2006a). Emotional exhaustion and organizational deviance: Can the right job and a leader's style make a difference? Journal of Business Research, 59(12), 1222-1230.

Mansor, N., Kamarudin, A., \& Zakaria, N. H. (2012). Employees' satisfaction in selecommunication industries: A case of Telekom Malaysia Berhad. European Journal of Scientific Research, 96(1), 24-37.

Munir, F., Nielsen, K., \& Carneiro, I. G. (2010). Transformational leadership and depressive symptoms: a prospective study. Journal of Affective Disorders, 120(1-3), 235-239.

Naile, I., \& Selesho, J. M. (2014). The role of leadership in employee motivation. Mediterranean Journal of Social Sciences, 5(3), 175-182.

Nami, A., Mansouri, M., Dehnavi, A., \& Bandali, E. (2013). Relationship between coaching leadership styles and athletic stress in team sports from universiti of Tehran. European Journal of Experimental Biology, 3(2), 48-53.

Nyberg, A., Holmberg, I., Bernin, P., Alderling, M., Akerblom, S., Widerszal-Bazyl, M., Magrin, M. E., Hasselhorn, H., Milczarek, M., D’Angelo, G., Denk, M., Westerlund, H., \& Theorell, T. (2011). Destructive managerial leadership and psychological well-being among employees in Swedish, Polish, and Italian hotels. Work, 39, 267-281.

Ojokuku, R. M., Odetayo, T. A., \& Sajuyigbe, A. S. (2012). Impact of leadership style on organizational performance : A case study of Nigerian Banks. American Journal of Business and Management, 1(4), 202-207.

Rao, M. S. (2013). Soft leadership: A new 
Choi Mui Fong, Floriana Lendai ak Michael Mulok, and Helmi Sumilan

direction to leadership. Industrial and Commercial Training, 45(3), 143-149.

Rohmann, A., \& Rowold, J. (2009). Gender and leadership style: A field study in different organizational contexts in Germany. Equal Opportunities International, 28(7), 545-560.

Romanowska, J., Larsson, G., \& Theorell, T. (2013). Effects on leaders of an art-based leadership intervention. Journal of Management Development, 32(9), 1004-1022.

Rusli Ahmad, Hasbee Usop, Sopian Bujang, Azman Ismail, \& Nur Naha Abu Mansor (2014), Conducting research in social sciences, humanities, and management studies. A stey by step guide. Malaysia, RS Publishing House.

Shafie, B., Baghersalimi, S., \& Barghi, V. (2013). The relationship between leadership style and employee performance. Singaporean Journal of Business Economics, and Management Studies, 2(5), 21-29.

Skakon, J., \& Nielsen, K., Borg, V., \& Guzman, J. (2010). Are leaders' well-being, bahaviours and style associated with the affective wellbeing of their employees? A systematic review of three decades of research. Work \& Stress, 24(2), 107-139.

Voon, M. L., Lo, M. C., Ngui, K. S., \& Ayob, N. B. (2011). The influence of leadership styles on employees' job satisfaction in public sector organizations in Malaysia. International Journal of Business, Management and Social Sciences, 2(1), 24-32.

Yao, Y.H., Fan, Y.Y., Guo, Y.X., \& Li, Y. (2014a). Leadership, work stress and employee behavior. Chinese
Management Studies, 8(1), 109126.

Zehir, C., Sehitoglu, Y., \& Erdogan, E. (2012). The effect of leadership and supervisory commitment to organizational performance. Procedia - Social and Behavioral Sciences, 58, 207-216. 